\title{
The Cultural Revolution and Its Legacies in International Perspective
}

Julia Lovell

\begin{abstract}
This article explores the rhetoric and reality of the Cultural Revolution as an international phenomenon, examining (through published and oral histories) the ways in which it was perceived and interpreted beyond China. It focuses in particular on the diverse impact of Maoist ideas and practice on the counterculture movement of Western Europe and North America during the late 1960s and 1970s. Within Europe, Cultural Revolution Maoism galvanized Dadaist student protest, nurtured feminist and gay rights activism, and legitimized urban guerrilla terrorism. In the United States, meanwhile, it bolstered a broad programme of anti-racist civil rights campaigns and narrow Marxist-Leninist party-building. Despite Mao's hopes to launch a global permanent revolution, it appears that, over the long term, enthusiasm for the Cultural Revolution in Western Europe, the United States and parts of South-East Asia helped to splinter the radical left and assisted the right in consolidating its power throughout the 1980s and beyond.
\end{abstract}

Keywords: Cultural Revolution; Maoism; Western Europe; United States; Singapore

In spring 1966, as the opening struggles of the Cultural Revolution began, Ditu Publishing House issued a new map of the world. The map, in which the People's Republic of China occupied the centre, was headlined by a quotation from Mao: "The socialist system will eventually replace the capitalist system; this is an objective law independent of man's will. However much the reactionaries try to hold back the wheel of history, eventually revolution will take place and will inevitably triumph." To the left and right, the map was framed by two lines from a 1963 poem by Mao: "The four seas are rising, clouds and waters raging/The five continents are rocking, wind and thunder roaring."

The map expressed the international hopes of "Mao's last revolution" in its early, expansively utopian phase. Other print media voiced a similarly global message. Issues of Peking Review through 1966 and 1967 reported in several languages on the worldwide multitudes of Mao's admirers - Sri Lankan trade unionists, Malian craftsmen, Argentine opthalmologists, Italian publishers, Guinean

* Birkbeck, University of London. Email: ubra235@mail.bbk.ac.uk. 
dancers, Syrian journalists, Congolese soldiers, Venezuelan pirates and Mexican schoolgirls. Western diplomats and politicians took this rhetoric about the diffusion of Maoism literally, pointing to "a programme for Maoist world domination" reminiscent "of Hitler's Mein Kampf." Accusing Mao's China of international schemes of subversion and guerrilla warfare, the Australian prime minister in 1966 warned his parliament that, "we face a future in which the security of Australia is in jeopardy." 1

Peking Review inevitably overstated international adulation of Mao and his Cultural Revolution. Nonetheless, the culture and politics of Cultural Revolution China did permeate global radicalism during the 1960s and 1970s. Mao and his ideas of continuous, peasant revolution appealed to left-wing rebels as well as civil-rights and anti-racism campaigners in the US, Australia and Western Europe. Across the developing world in Asia, South America and Africa, Maoist politics inspired post-colonial nations with idioms such as selfreliance, party rectification and revolutionary spontaneity. This article explores the rhetoric and reality of the Cultural Revolution as an international phenomenon, examining the ways in which these events were perceived and interpreted beyond China. It focuses in particular on the diverse impact of Maoist ideas and practice on the counterculture movement of Western Europe and North America during the late 1960s and 1970s. Within Europe, Cultural Revolution Maoism galvanized Dadaist student protest, nurtured feminist and gay rights activism, and legitimized urban guerrilla terrorism. In the United States, meanwhile, it bolstered a broad programme of anti-racist civil rights campaigns and narrow Marxist-Leninist party-building.

In his article for this volume, Frank Dikötter argues that several of the domestic results of the Cultural Revolution were unintended, or even the reverse of what had been planned. A similar argument can be advanced for the spread of Cultural Revolution Maoism in the territories under consideration here. Mao and his supporters envisioned the Cultural Revolution as launching a global movement against revisionism that would mobilize the grassroots to dismantle imperialism and bureaucratism within governments across the world. Yet, it appears that over the long term, enthusiasm for the Cultural Revolution splintered the radical left and assisted the right in consolidating its power through the 1980s and beyond. One outcome of the instability of the late 1960s in the US and Europe was the gradual shifting of consensus in favour of order and the reinforcement of hierarchies of established power on the right - paving the road to Ronald Reagan and Margaret Thatcher by the early 1980s - a trend that has not significantly reversed itself since. ${ }^{2}$

1 Scott 2007, 53-54.

2 See, e.g., Harvey 2005, although Harvey does not contend that the extreme left was the only phenomenon driving the rise of neoliberalism. Instead, he argues that a combination of factors operated, including fiscal crisis, a renewed drive for collective identity and action among Anglo-American business interests, longstanding hostility to the welfare state, and the individualism inherent to the counterculture left of the 1960s and 1970s. Slavoj Žižek also argues for a direct connection between Maoism and the 
It would be misleading, however, to argue that the legacy of the global Cultural Revolution was obliterated by, or indeed wholly responsible for, the rallying of right-wing politics. Although the history of Indian Maoism lies beyond the scope of this essay, in central and eastern India the currently resurgent Maoist Naxalite movement (which coheres in part around memory of its earliest, Cultural Revolution-inspired incarnation in 1967) is considered the "single biggest security challenge to the Indian state." 3 In his discussion of the Cultural Revolution, Wang Hui has argued that its significance lies in its facilitation of political debate about party, state, society and economy - a kind of debate that has largely been eliminated in the course of the post-Mao negation of the Cultural Revolution. ${ }^{4}$ And, although this article will by no means mute the tragedies, absurdities and misapprehensions of the Cultural Revolution's global travels, it will also consider the possibilities of more positive legacies of far left-wing politics beyond China, such as civil activism. It will explore whether there is a story to be told about the expansion of Maoism that also led to the dissemination of ideas, such as "serving the people," "consciousness-raising" and "cultural revolution" in education, that have had a broad impact on politics outside of China, for instance on feminist, gay rights, racial equality, environmental and academic movements. In West Germany, for example, Maoist-influenced parties became tributaries feeding into the later green movement of the 1980s.

The global travels of Maoism in general, and of the Cultural Revolution in particular, have become the focus of increasing academic attention in recent years. We currently possess accounts of the impact of Cultural Revolution Maoism on some individual national territories, for example on France, Richard Wolin's The Wind from the East (2010), and on Italy, Roberto Niccolai's Cuando la Cina era Vicina (1998). ${ }^{5}$ Within the last year alone, two volumes of essays on global Maoism have been published. ${ }^{6}$ But the existing literature for the most part deals with individual countries - Maoism in France, India and so on. Occasionally, two countries are considered alongside each other, for example the US and France in Belden Fields' Trotskyism and Maoism: Theory and Practice in France and the United States. ${ }^{7}$ However, atomized national studies are more often the norm. The two books that aim at more comprehensive coverage of global Maoism, Robert Alexander's International Maoism in the

\footnotetext{
footnote continued

triumph of neoliberalism, although through a very different process. In Žižek's account, the Maoist concept of Cultural Revolution philosophically paves the way for "the reign of today's global capitalism": both represent "Lords of Misrule." See Žižek 2011, 696.

3 Chakrabarty 2014, 118.

4 Wang, Hui 2009, 9-11.

5 Wolin 2010; Niccolai 1998. There is, incidentally, no English-language monograph on the influence of Maoism within the majority of West European states, for example within Italy, West Germany or Norway.

6 Cook 2014; Wang, Ning 2015 and other essays in 2015 Comparative Literature Studies 52(1).

7 Belden Fields 1988.
} 
Developing World and his Maoism in the Developed World, are reference books of discrete national case studies, each a few pages long, a form which does not lend itself to sustained comparative analysis. ${ }^{8}$

This essay aims to break new ground by exploring and comparing the impact of the Cultural Revolution across Western Europe, the US and Singapore, drawing on published and oral histories in several languages. This transnational approach makes it possible to explore the commonalities and specificities of the reception of the Cultural Revolution in different territories, and the local conditions that account for such particularities. Western enthusiasm for the Cultural Revolution is an exemplary episode in a much longer history of encounters often marked by selective understanding, reinterpretation and distortion between China and the rest of the world. For this reason, perceptions of the Cultural Revolution in the US and Western Europe tell us far more about those countries than they do about the Cultural Revolution itself. It is notable, for example, that across Western Europe, Maoist sympathizers in Italy and West Germany - the two countries with the strongest fascist pasts - veered furthest into political violence. Comparative analysis also facilitates the drawing of broader conclusions about the legacy of the Cultural Revolution, namely by tracing a link between the radical upsurge of which Maoist influence was an important part in the 1960s and 1970s, and the fight-back of the political right-wing through the 1980 s and beyond.

My argument will be developed through four sequential sections. The essay will begin by accounting for Cultural Revolution fever in the late 1960s, connecting it to the decade's broader counterculture rebellion. The subsequent two sections will chart the radicalization of Maoist politics in countries including West Germany, Italy, France and the US, through party-building and terrorist activity. The fourth part will analyse the long-range impact of Cultural Revolution-infused radicalism on political, cultural and intellectual trends in the US and Western Europe since the 1970s.

\section{The Spiritual Atom Bomb Detonates: Cultural Revolution in Western Europe and the United States}

In 1965, the Chinese minister of defence, Lin Biao 林彪, actively encouraged the global export of Maoist revolution in his widely publicized essay, "Long live the victory of people's war":

Comrade Mao Zedong's theory of the establishment of rural revolutionary base areas and the encirclement of the cities from the countryside is of outstanding and universal practical importance for the present revolutionary struggles of all the oppressed nations and peoples ... [I]f North America and Western Europe can be called "the cities of the world," then Asia, Africa and Latin America constitute "the rural areas of the world" ... the contemporary world revolution also presents a picture of the encirclement of cities by the rural areas ... Mao Zedong's thought is a common asset of the revolutionary people of the whole world. 
This is the great international significance of the thought of Mao Zedong ... All peoples suffering from US imperialist aggression, oppression and plunder, unite! Hold aloft the just banner of people's war ... Victory will certainly go to the people of the world! ${ }^{9}$

Upping his rhetoric in 1966, Lin Biao described the book of Mao's quotations, the "little red book" - of which more than a billion copies were printed in dozens of languages between 1966 and 1971 - as a "spiritual atom bomb of infinite power." 10 Across the 1960s, the architects of the Cultural Revolution thus explicitly promoted Mao's theories as the key to launching successful foreign revolutionary wars.

Chinese activists identified a single motivation for global adulation of the Cultural Revolution - admiration for China's struggle against imperialism. This assumption was not groundless. The enthusiasm for Mao Zedong across Western Europe and the United States converged with fierce opposition to American and Soviet foreign policy. During the 1960s, Mao and his Cultural Revolution became a space in which the left wing imagined a "better world," even as this global ideal fractured between local concerns and misreadings. ${ }^{11}$

A sense of solidarity with Third World independence struggles drove sympathy for Cultural Revolution Maoism in the United States and Western Europe. Max Elbaum - participant, observer and later historian of the American "new left" of the late 1960s and early 1970s - spells out the direct connection between condemnation of American foreign policy (as distinctively imperialist) and American radicals' pro-China turn.

[O]nly after 1968 ... did Marxism spread widely among sixties activists. Washington's stubborn continuation of the war in Vietnam was a prime factor in this ideological shift. Despite massive protest at home, international isolation, growing economic difficulties and ... overwhelming evidence that victory was impossible, the US refused to withdraw. Something beyond a single misguided policy simply had to be operating. Young activists ... identified that something as the drive of an imperial system to defend its worldwide sphere of influence. ${ }^{12}$

Horror at the Vietnam War drew millions of protestors onto the streets and Ho Chi Minh was lionized as the leader of Vietnamese resistance to the United States. Yet, Mao's China commanded greater political allegiance because it was seen as having originated the successful formula for "asymmetrical" guerrilla warfare in operation in Vietnam. It was the "high Maoist" strategy summarized by Lin Biao in "Long live the victory of people's war" that seemed to provide a blueprint for Vietnamese and other contemporary independence struggles. Through the Cultural Revolution, the People's Republic portrayed itself as "a new center for the world revolutionary movement (in a way that the Cuban and Vietnamese parties did not) and promoted itself as the shining example and prime champion of liberation movements waged by people of color all over the world." 13

13 Ibid., 45. 
In West Germany, Cultural Revolution China's self-styling as the vanguard of global anti-imperialism also appealed to the 1960s "new left." Rudi Dutschke (later dubbed the "Berlin prophet" of Mao Zedong) rather presumptuously declared in 1964 that "[i]n the judgement of the character of our era, an era of national liberation in Asia, Africa and Latin America, I am Chinese." 14 Gerd Koenen terms the revolutionary Third World the "defining discovery" of the 1960s protest movement in West Germany. ${ }^{15}$ Dutschke, Koenen argues, equated violent protest in his country with independence wars in the Third World - both formed part of a global project to overthrow global capitalism - and seemed to believe that the model of guerrilla warfare held for West Germany as it did in Asia, Africa and Latin America. ${ }^{16}$ A cell of radical students in 1969 referred admiringly to Lin Biao's theories of "encircling the city from the countyside" in their plan to politicize the Bavarian countryside around Munich by recruiting cadres in rural discotheques. ${ }^{17}$ The protest culture of the late 1960s was politically polyglot: a mash-up of Herbert Marcuse, Che Guevara, Ho Chi Minh, Amilcar Cabral and Wilhelm Reich, the Freudian pioneer of free love and orgasms. Yet, amid this smorgasbord of influences, the theory and practice of Cultural Revolution Maoism exercised a particular fascination. Indeed, Maoist language was so ubiquitous throughout Italy in the late 1960s that neo-fascists scrawled on Florentine walls the same Cultural Revolution slogans - "It's right to rebel" and "Bombard the headquarters" - that were being shouted by left-wing students in Milanese piazzas. ${ }^{18}$

In the United States, the struggle against oppression of non-white people had a powerful local relevance in the context of the civil rights movement (which politically awakened many activists before the anti-Vietnam War movement escalated). For dispossessed ethnic groups in the second half of the 1960s who began to identify themselves as "internal colonies" within the US, Mao's antiimperialist stance resonated. "For blacks, Latins and Asians, and the whites who identified with the Third World, Mao was Marx and Lenin and Stalin but he wasn't white," observed Ethan Young, a middle-class white student activist in the late 1960s. ${ }^{19}$ Mao also had a strong message for other sectors of American society agitating against the establishment, declaring in 1968 that "the Afro-American struggle is winning sympathy and support from increasing numbers of white working people and progressives in the United States. The struggle of the Black people in the United States is bound to merge with the American workers' movement, and this will eventually end the criminal rule of the US monopoly capitalist class." 20 Dennis O'Neil, one of many white students

Gehrig 2011, 204; Slobodian 2012, 173

15 Koenen 2001, 46-47.

16 Ibid., 49.

17 Slobodian 2012, 194.

18 Niccolai $1998,70$.

19 Interview with Ethan Young, New York, 24 March 2015.

20 Mao 1968. 
radicalized by the civil rights movement, spoke of the impact that this statement had on him: "Mao identified the two main elements of the united front, the struggle of the black masses and the working class, and said that they were "bound to merge' ... This says, if you want to get black freedom, you have to overthrow the system, and the black masses and masses of working people have common interests." 21

For high-profile activists in the African-American Liberation Movement in the late 1960s, the "little red book" seemed almost made for the turbulence of black militancy. The appeal lay not only in its message of supporting anti-colonial armed struggles, of advocating guerrilla warfare and of building a vanguard party, but also in its style and design. It was easy to understand (and therefore ideal for teaching low-literacy recruits), physically compact and hardily packaged in red vinyl. In early 1967, the founders of the Black Panther Party, Huey Newton and Bobby Seale, sold copies of the little red book to students to make money to buy guns. Once the shotguns had been purchased, remembered Seale, "[we] used the Red Books and spread them throughout the organization ... Where the book said, 'Chinese people of the Communist Party,' Huey would say, 'Change that to the Black Panther Party. Change the Chinese people to black people'."22 The Revolutionary Action Movement (RAM; arguably the first US organization to try to harness urban unrest among black populations for revolutionary purposes) freely borrowed Cultural Revolution terminology in its public statements: "America is the Blackman's Battleground. Support the Black Cultural Revolution. Join the BLACK GUARD!"23

Across Western Europe and the US, Cultural Revolution Maoism stood not just for anti-imperialism but also for youthful rebellion. In each of the countries in which Cultural Revolution fever took hold, youthful protest movements had personal and local, as well as international, reasons for revolt. Students in Western Europe resented their cramped institutions of higher education. In Italy, the student population more than doubled in the 1960s, without any coterminous expansion of university facilities. By 1967, students were frustrated by their overcrowded living and teaching conditions. The privations suffered by southern workers migrating north, meanwhile, turned Italy's industrial heartland into a tinderbox of discontent that would come alight during the "hot autumn" of 1969. Between 1950 and 1968, numbers of students had almost quadrupled in West Germany, where student hostility to the establishment was intensified by suspicions about its Nazi past. Between 1966 and 1968, for example, accusations swirled that Heinrich Lübke, the president of the Federal Republic of Germany (FRG), had been complicit in the building of concentration camps. Cultural Revolution Maoism told the discontented and the young that "it was right to rebel"; that "young people, full of vigour and vitality, are ... like the sun at 
eight or nine in the morning ... The world belongs to you."24 At one anti-Social Democratic Party demonstration in West Berlin in 1969, the students chanted paraphrastically: "You are old, we are young, Mao Tse-Tung!"25

It is no coincidence that the Cultural Revolution, in the memories and publications of white American students swept up in the 1968 protest movement, did not attract significant interest until 1968. The Cultural Revolution inspired many US students only when it chimed with their own anti-establishment project: "1968 hit and students looked around for validating events all over the world," remembered Dennis O'Neil. "Before then, we hadn't paid attention to the Cultural Revolution."26 "The Cultural Revolution," Ethan Young contends, "was seen as the student movement in power. It was a successful, world-changing version of what was going on in Paris, Berkeley, West Berlin." 27 For those with a background of communist sympathies, China's Cultural Revolution offered an alternative to the Soviet Union: revolution within the revolution. "The attraction for young people who didn't have any connection with communism," remembered Dennis O’Neil, “was the idea of putting dunce hats on your high school teachers."28 American identification with the aims of the Cultural Revolution in 1968, therefore, is far more informative about the preoccupations of these distant observers of Chinese politics than about Chinese politics itself.

In West Germany, rebellious students imitated the political behaviour of the Cultural Revolution as part of a broader project of Bürgerschreck (shocking the bourgeoisie). They reproduced translations of Chinese big-character posters and wrote their own, and they recited Cultural Revolution speeches during their occupations of university buildings. In November 1966, student representatives rushed into a meeting with the president of the Freie Universität wearing Mao badges and calling themselves "Red Guards" before presenting a range of very local protests: "We have to cope with poor working conditions, miserable lectures, stupefying seminars, and absurd exam requirements." 29 On a blackboard behind the students gathered at one meeting of the West German Socialist Student Union in 1967, someone had scrawled the Maoist dictum: "To rebel is justified." 30 "To stick on a Mao button," remembered Gerd Koenen, "recite the words of the Great Chairman, or pin his smiling portrait to the wall as the Mona Lisa of the world revolution signified the most radical and striking antithesis to the 'old' bourgeois world." 31 Students gleefully remade the rhetoric and political theatre of the Cultural Revolution into an anarchic Dada-Maoism. Dieter Kunzelmann, one of the most prominent Maoist

31 Slobodian 2012, 178. 
sympathisers, was linked with the French Situationists and the Dutch Provos two artistic groups of the 1950s and 1960s ambitious to make political rebellion through cultural provocation. ${ }^{32}$ Mao's words played a role in many of the publicity stunts carried out by West Germany's first political commune, Kommune 1, founded in 1967 by Kunzelmann and Dieter Langhans. In a text planning the commune, Kunzelmann quoted Mao's irreverent view on intellectual authority: "dogma has less value than cow dung. At least dung can be used as fertilizer." 33

Against this backdrop of youthful turbulence, specific aspects of Mao's Cultural Revolution's programme (as communicated through Peking Review) appealed across Western Europe and the US: its apparent advocacy of the "mass line" and of political participation from the grassroots. Raymond Lotta, an early recruit to the Revolutionary Union (the largest pro-Maoist white American party of the 1970s), recalled:

We were outraged by the brutal oppression of black people and the genocidal war in Vietnam ... and by the workings of capitalism and imperialism. We saw socialism in China and the Cultural Revolution as the model for the liberatory solution. This was a "total revolution" - creating an economy and social institutions to serve the people, and mobilizing people to uproot the oppression of women, revolutionize culture and values, and overcome the great chasm between mental and manual labor. Maoist China was inspiring and supporting revolution throughout the world. And for ten years, the Cultural Revolution prevented the restoration of capitalism and the return of all its horrors, what we see in capitalist China today. ${ }^{34}$

The Cultural Revolution's "anti-bureaucratic content and demands that education serve the people resonated massively," recollected Dennis O’Neil.

I made the same evolution as hundreds of thousands of people in that age cohort ... At first you're against the [Vietnam] war because war's horrible ... And then you're against the war because it's a system: the system of imperialism, which has to have wars. So we need to have a revolution: the civil rights movement had won some battles but not freedom from oppression. What kind of revolution? A socialist revolution. And the Cultural Revolution is the gateway drug to that. Mao says that the masses are the makers of history. This is very important to us because we came out of movements, like civil rights, that were based on that: on ordinary, everyday people facing down horrific terror to register to vote. ${ }^{35}$

\section{From Playful to Party: The Disciplining of Dada-Maoism}

After 1968, Cultural Revolution Maoism in West Germany, Italy, France and the US became a more disciplined, authoritarian phenomenon, seemingly offering a way forward for the disintegrating student movement. It provided a blueprint for creating vanguard parties (based on the organizational model of the CCP) that could carry out grassroots revolutionary work in factories and sometimes in rural areas. Almost all such parties pledged unswerving loyalty to the PRC's policies. This shift towards party-building once more highlights the importance of local factors and conditions in determining the ways in which West Europeans and Americans engaged with the Cultural Revolution. It also constituted a 
crucial intermediate stage in the evolution of some of these groups towards violent political extremism, and in the steady fracturing of the left during the 1970s.

In West Germany, the student movement petered out with the passing in 1968 of a new state emergency law (an issue that student activists had hoped to use to build an alliance with the trade unions). Unable to access the trade unions' nationwide organizational base, activists decided to turn to tighter forms of organization: they became interested in an image of Mao not as a provocative jester but instead as a tough party man. Kommune 1 was replaced by a host of Marxist-Leninist cadre parties, the so-called K-Gruppen (the $\mathrm{K}$ standing for Kommunistischen, communist, groups), such as the Kommunistischer Bund Westdeutschland (KBW), the re-formed Kommunistische Partei Deutschlands (KPD), and the Kommunistische Partei Deutschlands/Marxisten-Leninisten (KPD/ML).

Andreas Kühn, author of the most comprehensive monograph on the K-Gruppen, emphasizes the ideological rigidity of these parties. They fixated, he writes, on an idea of "correct" revolutionary practice to be instilled through Chinese communist practices and through subscription to the Chinese line on foreign affairs. Life within the K-Gruppen demanded absolute submission to party demands and exhausting self-criticism sessions. The thoughts of Mao seemed to take on a quasi-religious dimension, providing a complete and completely superior worldview, with the answer to everything, including the prevention of natural disasters and the healing of life-threatening injuries. Kühn views the K-Gruppen as "political sects using structures and techniques involving the destruction of individualism, unconditional obedience, isolation, and a vague, confused idea of personal redemption." 36

Perhaps as many as 3,000 young French Maoists made major lifestyle sacrifices for their beliefs. They abandoned the natural career paths of France's educated elite - a large number came from France's pre-eminent institution of higher education, the École Normale Supérieure (ENS) - for stints "serving the people" (working in factories or in the countryside) as "établis." Others undertook "long marches" through the countryside in order to gain a better understanding of the conditions of the French proletariat. They repeated Mao's terse dictum, "no investigation, no right to speak," as a litany. "I've always kept in mind a quotation from President Mao, which I still like and say a lot," recalled a prominent member of the ENS group, Tiennot Grumbach, in 2008. "There are those who cross the field without seeing the roses, there are those who stop their horse to look at the roses, and there are those who get off their horse to smell the roses.' That was our idea: to smell the roses. And for us, the roses were the workers." 37 Olivier Rolin, leader of the military wing of the largest post-1968 Maoist party, Gauche Prolétarienne (GP), labelled établissement a flight, "exactly like the Exodus ... the result of a quite radical reflection on the crisis of the 
intellectual." 38 There was a self-loathing, self-destructive quality to French Maoism that was highly susceptible to the anti-intellectualism and anarchic politics of the early Cultural Revolution.

In the US, the "new communist" movement - an assortment of mainly Maoist parties that sprang out of the faltering student movement of the late 1960s - aspired to form a basis on which the new left could organize. "Maoism broadly appealed through its emphasis on serving the people, its idea that the correctness of the political line determines everything," recalled Ethan Young. "But at the same time people realized they lived in a country that had a lot of deep-rooted social as well as political conservatism. The harder that we attempted to practise rebellion, the more difficult we found the process of actually changing people was ... So we looked for vehicles, formulae, means to bring about the kind of changes we wanted ... China during the Cultural Revolution represented a particular model for a particular time." 39

As in West Germany, this quest for a successful revolutionary model often morphed into a slavish adherence to Chinese foreign policy decisions, to techniques of party-building, and to the concept of sending cadres and party members "among the people" to organize local communities and factory workers. The Red Guards in San Francisco and their successor organization, I Wor Kuen (two Asian-American, pro-Mao groups), for example, absorbed Maoist injunctions on party discipline: "We studied the rules of the [CCP]," recounted Alex Hing, a leading member. "If we felt that somebody messed up then we had a criticism-self-criticism ... We did mass work." ${ }^{40}$

The numbers involved in these parties were not enormous. At their peak, the K-Gruppen probably drew in somewhere between 100,000 and 150,000 individuals. ${ }^{41}$ Some estimate a maximum of $800-1,000$ members of the Revolutionary Union during the 1970s; perhaps 150 remain in its successor organization, the Revolutionary Communist Party, today. During its heyday in the first half of the 1970s, I Wor Kuen could probably call upon around 2,000 cadres. At the peak of the movement in the 1970s, there were around 7,000 French Maoists. ${ }^{42}$ Yet, in France, for example, Maoist parties punched above their numerical weight thanks to the cultural influence that they commanded, which owed significantly to their ability to attract talented writers and intellectual celebrities to their cause. The militant French Maoist party, GP, gained much lustre from the support of Jean-Paul Sartre and Simone de Beauvoir.

Extreme sectarianism resulted from the quasi-religious dogmatism with which West German, American and Italian Maoist parties interpreted the Chinese model. Indeed, in almost all of their West-European and North American guises, Maoist parties were about as enthusiastic about consensus-building as the

42 Bourseiller 1996, 18. 
People's Front of Judea in the Monty Python comedy, The Life of Brian. In the United States, the 1960s left wing later divided into over 50 groupings that subscribed in some degree to Maoist ideas and outlook. ${ }^{43}$ Ethan Young was an eyewitness to the factionalism of US Maoist party-building in the mid-1970s. "The machine shop I was working in on the south side of Chicago was a focal point for many different, mostly Maoist, groups ... I found myself lost in the alphabet soup, and getting used to approaches from all sorts of different groups, and having people say to me, did you hear what these jerks did last week, look at this leaflet they put out."44 Young's recollection conjures up a paradoxical picture of former students-turned-Maoists clogging the grassroots, all competing fractiously to recruit each other and somehow failing to reach the real proletariat.

\section{The Cultural Revolution Legacy and the Politics of Terror}

Some analysts have directly linked the Cultural Revolution-inspired radicalism of the late 1960s to the terrorism of groups such as the Red Army Faction (RAF) in West Germany and the Red Brigades in Italy, both of which posed serious threats to the stability of the states within which they operated. Indeed, the police and security services in countries where pro-Mao groups emerged viewed any form of Maoist politics as a credible menace: the French police kept extensive files on Maoist groups, and in the USA, the FBI and CIA waged war on the Maoist-influenced radical movements of the 1960s and 1970s through the infamous, and often illegal, COINTELPRO and MHCHAOS. In West Germany and Italy, in particular, the state's security apparatus would succeed in strengthening itself in the second half of the 1970s in response to Maoist-infused political violence, as will be discussed in the subsequent section.

The rhetorical militancy of Maoism and the Cultural Revolution was undoubtedly an influence on those members of the West German student movement who chose to cross over to a violent, underground revolution. Sebastian Gehrig argues that the Maoist theory of "permanent revolution" led to parts of the student movement seeking ever more extreme positions from which to continue the revolution after the protests faltered in $1968 .{ }^{45}$ While some revelled in the radical-chic burgerschreck of the student movement's reading of the Cultural Revolution, for others Maoism validated violent rebellion against the FRG state apparatus - an apparatus that the student movement had denounced as genocidal (through its alliance with US foreign policy) and fascistic (owing to its Nazi connections and brutal clashes with student protestors). Several West Germans who later migrated to terrorism were steeped in the general Maoist mood of the late 1960 s protests. Two of the founding members of the RAF, Andreas Baader

43 See: http://freedomroad.org/2000/02/family-tree-introduction/ for a visual guide to these parties. There is a "basic" and a "mega" family tree; visitors to the page are warned that their "browser may have trouble" with the complexity of the latter. See Bourseiller 1996, 331, for a French counterpart.

44 Interview, Ethan Young.

45 Gehrig 2008, 156. 
and Gudrun Ensslin, waved little red books in the air at their first trial in Frankfurt. At an early stage in their thinking on urban warfare, they marshalled (sporting Mao buttons on their leather jackets) some 50 young people from a care home into a militant group and gave them lessons on the "little red book." 46

The RAF's first manifesto, on "The urban guerrilla concept," was larded with quotations from Mao: "We must draw a clear line between ourselves and the enemy"; "without investigation there cannot possibly be any right to speak"; "imperialism and all reactionaries [are] paper tigers"; "whoever is not afraid of being drawn and quartered, can dare to pull the emperor from his horse." $47 \mathrm{~A}$ further theoretical document of 1972 argued that all violence committed by the RAF was to "serve the people." ${ }^{48}$ Mao's works thus created the initial frame of reference for the RAF, a frame of reference that exercised an assured appeal over parts of the protest movement. Till Meyer, who would later join another terrorist group, the 2 June Movement, and take part in the 1975 kidnapping of Peter Lorenz, a mayoral candidate for West Berlin, which successfully bargained for the release of jailed RAF members, recalls his initial response to "The urban guerrilla concept" when a copy was thrust into his hands at a demonstration: "At the top, I saw the Mao quotation. I greedily drank the whole pamphlet down. I was enthused." 49

Maoism had a similar influence on the Red Brigades in Italy, which from 1970 declared war on the Italian political, economic and judicial establishment, played out in acts of "people's justice" and "proletarian violence" against "the bosses and their lackeys." Renato Curcio, one of the founders of the Red Brigades, had imbibed the late 1960s enthusiasm for the Cultural Revolution. Alberto Franceschini, later his close comrade in the Red Brigades, describes Curcio standing at the front of his university (Trento) wearing a t-shirt sporting a picture of Mao and handing out copies of the little red book. ${ }^{50}$ The earliest leaflets of the Red Brigades claimed that theirs "was a resistance oriented towards President Mao's revolutionary China." 51 Franceschini recalled of the Brigades' first kidnapping that they decided to hang around the neck of their victim, a business executive, a notice on which was written: "Kill and flee. Nothing goes unpunished. Strike one to educate one hundred." "We got," Franceschini remembered, "Kill and flee' from Mao. He had written that the principle of partisan tactics is to kill and immediately run away." ${ }^{2}$ In the militant circles in which the Red Brigadists moved, Roberto Niccolai identified that "phrases, slogans, whole speeches were directly or indirectly dedicated to the Great Helmsman." 53

46 Koenen 2001, 175.

47 Smith and Moncourt 2009, 83-105.

48 Ibid., 122-159.

49 Ibid., 158.

50 Franceschini 1988, 19.

51 Niccolai 1998, 67.

52 Franceschini 1988, 62-63.

53 Niccolai 1998, 68. 
Theoretical subscription to the idea of a future, violent revolution was a thread that united many of the Maoist-inspired parties of the 1970s, across France, West Germany, Norway and the United States, even if they did not transform this conviction into homicidal action. In 1977, as the KBW grew convinced that the apocalypse of global capitalism was drawing nigh, the organization broadcast the idea that a decisive "armed uprising was the only way to remove the capitalist system in the FRG before it embarked on a new imperialistic world war." Military drills were carried out in parks so that cadres would be battle-ready. "A housewife used to modern kitchen and cleaning appliances," they hopefully conjectured, "would have no difficulty using a machine gun." 54

In 1966, RAM distributed "The world black revolution," a manifesto fronted by a picture of Mao and scattered with gobbets of Maoism and advocating allout urban guerrilla war against the white establishment. In the coming "War of Armageddon ... the 'devil's' forces of evil are destroyed by 'God' (Allah), the forces of righteousness ... Let the cry across the planet be 'burn, baby, burn'."55 After Robert Williams - the president of RAM who sought political exile in China between 1965 and 1969 - showed the manifesto to him, apparently even Mao thought they "might have taken it a bit far." 56

\section{The Cultural Revolution Legacy beyond the 1970s}

Conservative intellectuals - particularly those who have weighed into the "culture wars" of the past two decades - like to claim that, over the past half-century, young left-wing radicals of the 1960s have successfully undertaken a "long march through the institutions" (Rudi Dutschke's phrase), overrunning the establishment with politically correct values. It is true that the countercultural rebellion of which Maoism was a part decisively eroded social and cultural conservatism in the United States and Western Europe, and that the effects of this liberalization are still easily discernible in public life today.

The Western reception of Maoism had a direct influence on the women's and gay liberation movements, on educational reform and on aspirations to racial equality in public life. Tout! (the journal of the more liberal wing of French Maoism, the group Vive la Révolution) was a receptive venue for early explorations of women's and gay rights issues. "The idea of women holding up half the sky was all part of the influence of Mao," considers Dennis O'Neil. "The Cuban revolution was very macho ... The Maoist revolution had a very different feel: of social relations being transformed, not by diktat but from the ground up, by the participants themselves. Women modelled a lot of consciousness-raising groups on [China's] 'speak bitterness' meetings, with people denouncing the old ways, 
speaking out about the ways in which they're oppressed." 57 Andrew Ross, a professor of American Studies, argues that criticism-self-criticism, popularized by the Mao vogue, has passed into mainstream culture as "an important confessional ritual within the culture of popular therapy and self-help." The Cultural Revolution-inspired interlude of the 1960s and 1970s, he further contends, has contributed to reforms of secondary and tertiary education: "efforts to make curricula, teaching methods and access to learning ... more comprehensible, practical and accountable to socially denied communities." 58 It was, for example, associates of RAM who stayed in the educational system, such as John Bracey (at the University of Massachusetts from 1972), who contributed to the struggle for black studies in universities. The Asian-American Red Guards, and later I Wor Kuen, were involved in protests demanding the introduction of "ethnic studies" in American universities. A connection can be drawn between Cultural Revolution-inspired rebellion and the epistemological scepticism of poststructuralism - Michel Foucault went through a Maoist phase in the early 1970s. ${ }^{59}$ Sanjay Seth links Indian Maoism with the emergence of postcolonial and subaltern studies: Naxalite Maoism, he writes, made Indian intellectuals "engage with and in peasant struggles in a manner that left them more receptive to peasant consciousness." 60

Richard Wolin writes that former French Maoists have subsequently become "luminaries of French cultural and political life: philosophers, architects, scholars, and advisers to the Socialist Party." 61 Alain Geismar, former leader of the militant Gauche Prolétarienne, served through the 1990s in a succession of Socialist Party governments. Between 1973 and 2006, Serge July - another former GP leader - founded and edited Libération, a newspaper that originated from the organized Maoist left but evolved into an influential mainstream broadsheet. Andreas Kühn, in his monograph on the German K-Gruppen, argues that numerous West German ex-Maoists have (alongside other members of the FRG's radical left wing) enjoyed vigorous afterlives in mainstream politics, for the most part in the green movement. ${ }^{62}$

Much work remains to be done in tracing out the long-term impact of Maoist political ideas and practice on the political biographies of such individuals. It would be impossible, remembered Mario Capanna (who later served in the Italian Chamber of Deputies), "to deny the fascination that the Great Helmsman exercised over me ... [One] element of the fascination sprang from his great dialectical ability and the simplicity of his language. All the success

57 Interview, Dennis O’Neil. See Houten 2015 for further discussion of this point.

58 Ross 2005, 12, 15.

59 Wang, Ning 2015, 2-3.

60 Seth 2006, 602 .

61 Wolin 2010, 15.

62 Kühn 2005, 288. For details on the overlap between Maoist and environmental movements in Western Europe, see Tompkins 2013. 
that I achieved in the assemblies or, later, on the electoral platform, I owe to him." 63

But the success stories of Western Maoism perhaps feature disproportionately in public perception, obscuring the far more numerous casualties of this engagement. The tragic story of Robert Linhart is a case in point. In the mid-1960s, as leader of the breakaway Maoist faction in the French Communist Party, he was acclaimed as the brilliant "Lenin of L'École Normale Supérieure." In the throes of the May 1968 demonstrations, he suffered a nervous breakdown that confined him to hospital for months. In 1981, he attempted suicide with a massive overdose but eventually regained consciousness after weeks in a deep coma. He has barely spoken since. ${ }^{64}$

In certain cases, the Maoist upsurge of the 1970s succeeded in collectively dispiriting the radical left wing after its euphoric successes of the 1960s, and thereby facilitating the rise of right-wing, neoliberal governments during the 1980s. (Some analysts arrestingly argue that neoliberals actually borrowed from the language and techniques of the earlier Marxist-Leninist fever. David Priestland, after Ivan Molloy, asserts that Reagan's "low intensity conflict" was modelled on Maoist guerrilla warfare, and that the belligerence of his speeches against communism was inflected with the apocalyptic rhetoric of Marxism-Leninism. ${ }^{65}$ ) Max Elbaum blames Cultural Revolution fever for the marginalization of the contemporary American left, writing that "the most damage was done by Maoism" - by a dogmatic loyalty to the theory of the Cultural Revolution and to the twists and turns of Chinese domestic and foreign policy. "Maoism's problems were crystallized in Mao's Cultural Revolution slogan that 'the correctness or incorrectness of the ideological and political line decides everything.' This dictum was cited endlessly by the main Maoist groups, despite the fact that it completely ignored material conditions and the balance of political forces ... it not only fostered ultra-left analyses and tactics, but a theoretical purism that led directly to bitter confrontations over even minor points of doctrine and constant interorganizational competition." 66 After years of sectarian struggles, according to Elbaum, America's left wing was too exhausted to resist the conservative resurgence of the Reagan years witnessed in its assault on the trade unions and its tough line against socialist and communist governments in the Third World. Similar observations have been made about Italian Maoism. Italian Maoist groups of the 1970s, observed one insider, "were the product of an explosion of communism that fractured into a thousand splinters ... it was a crisis ... or only the fragment of a crisis ... It was the end."67

Ethan Young recalls the psychology prevailing among those who emerged from the American Maoist parties of the 1970s: "The sectarianism leaves the

67 Niccolai 1998, 236. 
scar. People who've lived through the sectarian wars react violently against suggestions of forming new parties ... They have memories of being lost in interminable debates and struggles that led nowhere. Some people's lives were torn apart; they were cast out of their groups. There were some suicides. And definitely a deep, deep demoralization, disillusionment and despair."68

Singapore's left-wing opposition party, Barisan Socialis, also ran a Cultural Revolution fever between the late 1960s and early 1970s that proved highly damaging to its long-term political health. After 1966, Barisan adopted a pro-Maoist framework for its political rhetoric, education and media, endorsing the Cultural Revolution's contempt for electoral politics and the Soviet Union's strategy of "peaceful evolution." This radical turn led all 13 Barisan MPs to resign from parliament, fatally weakening Barisan's political presence in Singapore. This "costly mistake," Lee Kuan Yew observed appreciatively in 2000, "gave the PAP [People's Action Party] unchallenged dominance of the Parliament for the next 30 years." 69 Party debates replicated Cultural Revolution-type factional struggles: Lee Siew Choh, chairman of Barisan from 1962, responded to internal dissent with Cultural Revolution-style denunciations. With political intolerance enshrined as a party principle, achieving a broader coalition of the left to oppose PAP became impossible. Yinghong Cheng concludes that "internal fights and schisms with Cultural Revolution characteristics," combined with Barisan's quest for ideological purity based on dogmatic interpretations of Mao's utterances, caused Singapore's left to implode. ${ }^{70}$ When Barisan returned to electoral politics in 1972, 1976 and 1980, it did not secure a single seat from PAP. According to this line of argument, PAP did not need to ban the party that in the early 1960s had been its main rival for power; Barisan in part extinguished itself through adherence to the Cultural Revolution. ${ }^{71}$ Naturally, factors other than Cultural Revolution influence also reduced the efficacy of the Singaporean left wing, in particular the pressure exerted on leftists during and after Operation Coldstore in 1963, an operation authored by PAP and British interests.

In her analysis of the post-1945 West German state, Karrin Hanshew argues that the climax of left-wing terrorism in 1977 ultimately increased the legitimacy of the FRG and empowered it to strengthen state security with a decisiveness that it had previously avoided for fear of comparisons with the Third Reich. ${ }^{72}$ Terrorism reoriented the West German left wing away from endorsement of violence and towards forms of peaceful protest often centred around environmental issues.

The first nine months of 1977 witnessed eight RAF murders and one kidnapping (of the industrialist Hanns Martin Schleyer). West Germany's emergency

68 Interview, Ethan Young.

69 Cheng 2011, 225.

70 Ibid., 238.

71 Luofu Ye advances a similar argument concerning the impact of Cultural Revolution politics on Hong Kong's left wing after the late 1960s. See Ye 2015, 81-82.

72 Hanshew 2012. 
became international when, on 13 October, four members of the Popular Front for the Liberation of Palestine hijacked a Lufthansa plane carrying 86 passengers, and included in their ransom demands the release of ten RAF members held in the Stammheim prison in Stuttgart. The FRG brought the hostage crisis to an end through a surgical strike on the plane at Mogadishu airport carried out by its new anti-terrorism squad; on learning of the failure of the hijacking on 18 October, three imprisoned RAF leaders (including Baader and Ensslin) committed suicide. That same day, the RAF members holding Schleyer executed him and abandoned his body in the back of a car.

These events - the crescendo of terrorist violence, together with the resolve of the West German state to mobilize security forces that had previously been shunned by a government nervous of raising the ghost of Nazi authoritarianism - caused the German left to abandon its widely held view of the West German state as a totalitarian enemy to which guerrilla violence was an acceptable response. According to Hanshew's analysis:

The political impotence and disillusionment [the extra-parliamentary left] felt ... prompted many to actively reengage the political mainstream and, correspondingly, to express an explicit and unprecedented appreciation for nonviolent politics ... By making German patriotism palatable and traditional values commonsensical, Mogadishu ... helped mainstream conservatives pursue a course of moral and national rejuvenation. ${ }^{73}$

For Cultural Revolution enthusiasts in organizations identified as genuine threats to the state, their commitment cost them dear. A former RAM activist pursued for years by the US security services reflected on the toll that political activism had taken on private life: "Half of my family is crazy, totally estranged. My oldest son is in penitentiary ... My children feel they grew up in a situation where I could not provide in the way that other fathers could." Nonetheless, he feels that Mao still has lessons for the African-American struggle today. "As we grew older, we really understood the nature of protracted struggles. It's been going on all our lives. Your strategy and tactics differ when you understand it's a protracted struggle. You learn retreat. All of that is in the philosophical principles of Mao."74

\section{Conclusion}

The Cultural Revolution's rhetoric of anti-authoritarian rebellion inspired revolts outside China that took aim at a broad range of political, cultural and social customs: at domestic and foreign policy; colonial rule; electoral representation; relations between the sexes; education, film and literature. The impact of the Cultural Revolution (upper-case) is part of a much more diffuse (and often liberalizing) process of cultural revolution (lower-case) that has transformed society, culture and politics since the 1960s, especially in the developed West. In countries riven by deep historical, ethnic or socio-economic fault lines (post-fascist

73 Ibid., 237. See Lumley 1990, 337-38 for similar remarks about the response of the Italian judiciary to left-wing terrorism.

74 Private communication. 
Germany and Italy; post-segregation America; post-independence India), the Cultural Revolution's legitimization of political violence served as the spark that lit a prairie fire - a fire that in some instances is still burning today. The United States is regularly jolted by revelations of racist police brutality; for veterans of the 1960s and 1970s African-American liberation struggle inspired by Cultural Revolution Maoism, some of the political ideas suggested by their readings of Maoist theory and practice remain relevant. More often, however, the rhetorical and actual violence of Cultural Revolution politics, in combination with the often dogmatic, sectarian way in which they were interpreted by radicals outside China, generated setbacks, both for the individuals who devoted so much time and energy to these ideas and for the left-wing causes in which they militated.

\title{
Acknowledgement
}

The author would like to thank Thelma Lovell for invaluable assistance with Italian and German language sources. She is also grateful for the helpful comments from the editors of this special issue, Robert Macfarlane and two anonymous reviewers. Especial gratitude is due to the Philip Leverhulme Prize, which made possible travel and research assistance.

\section{Biographical note}

Julia Lovell is reader in modern Chinese history at Birkbeck College, University of London. She is currently writing a global history of Maoism.

\begin{abstract}
摘要: 文章考察了文化大革命作为一种国际现象的修辞和现实状况, 并 (通 过已出版和口述历史文献) 对文革在海外被理解和诠释的方式进行了研 究。文章特别就 1960 年末和 1970 年代期间, 毛泽东思想及其实践对西欧 和北美的反文化运动的不同影响，进行了集中的论述。在欧洲，关于文化 大革命的毛泽东思想, 给达达主义 (Dadaist) 学生反抗运动提供了支持, 培 育了女权主义者和同志争取权利的激进主义，并为城市游击战恐怖主义提 供了合法依据。而在同时期的美国，毛泽东思想又为广泛的反种族主义民 权运动，以及狭义马克思列宁主义的政党建设，推波助澜。尽管毛泽东的 愿望是发动一场全球范围的持久革命，但从长远来看，在欧洲、美国和东 南亚部分地区，对文化大革命的热情，加速了激进左翼的分裂，而在 1980 年代和之后, 巩固和强化了右派的势力。
\end{abstract}

关键词: 文化大革命; 毛泽东思想; 西欧; 美国; 新加坡

\section{References}

Ahmad, Akbar. 1966. "The world black revolution," https://antiimperialism.files.wordpress.com/ 2012/10/ahmad-s.pdf. Accessed 12 May 2015. 
Alexander, Robert J. 1999. International Maoism in the Developing World. London: Praeger.

Alexander, Robert J. 2001. Maoism in the Developed World. London: Praeger.

Belden Fields, A. 1988. Trotskyism and Maoism: Theory and Practice in France and the United States. London: Praeger.

Bourseiller, Christophe. 1996. Les Maoistes: La Folle Histoire des Gardes Rouges Français. Paris: Plon.

Chakrabarty, Bidyut. 2014. Communism in India: Events, Processes and Ideologies. Oxford: Oxford University Press.

Cheng, Yinghong. 2011. "The Chinese Cultural Revolution and the decline of the left in Singapore." Journal of Chinese Overseas 7, 211-246.

Cook, Alexander (ed.). 2014. Mao's Little Red Book: A Global History. Cambridge: Cambridge University Press.

Elbaum, Max. 2006. Revolution in the Air: Sixties Radicals Turn to Lenin, Mao and Che. London: Verso.

Franceschini, Alberto. 1988. Mara Renato e Io: Storia des Fondatori delle BR. Milan: Arnoldo Mondadori.

Gehrig, Sebastian. 2008. “'Zwischen uns und dem Feind einen klaren Trennungsstrich ziehen': Linksterroristische Gruppe und maoistische Ideologie in der Bundesrepublik der 1960er und 1970er Jahre." In Sebastian Gehrig, Barbara Mittler and Felix Wemheuer (eds.), Kulturrevolution als Vorbild? Maoismen im deutschsprachigen Raum. Frankfurt: Peter Lang, 153-177.

Gehrig, Sebastian. 2011. "(Re-)configuring Mao: trajectories of a culturo-political trend in West Germany." Transcultural Studies 2, 189-231, http://journals.ub.uni-heidelberg.de/index.php/ transcultural/article/view/9072. Accessed 10 May 2015.

Hanshew, Karrin. 2012. Terror and Democracy in West Germany. Cambridge: Cambridge University Press.

Harvey, David. 2005. A Brief History of Neoliberalism. Oxford: Oxford University Press.

Houten, Christina van. 2015. "Simone de Beauvoir abroad: historicizing Maoism and the Women's Liberation Movement." Comparative Literature Studies 52(1), 112-129.

Koenen, Gerd. 2001. Das Rote Jahrzehnt: Unsere kleine Deutsche Kulturrevolution 1967-1977. Köln: Kiepenheuer \& Witsch.

Kühn, Andreas. 2005. Stalins Enkel, Maos Söhne: Die Lebenswelt der K-Gruppen in der Bundesrepublik der 70er Jahre. Frankfurt: Campus Verlag.

Lin, Biao. 1965. "Long live the victory of people's war!" https://www.marxists.org/reference/archive/ lin-biao/1965/09/peoples_war/index.htm. Accessed 13 May 2015.

Lin, Biao. 1966. "Foreword to the second edition of quotations of Chairman Mao Tse-tung," https:/l www.marxists.org/reference/archive/lin-biao/1966/12/16.htm. Accessed 13 May 2015.

Linhart, Virginie. 2008. Le jour où mon père s'est tu. Paris: Editions du Seuil.

Lumley, Robert. 1990. States of Emergency. London: Verso.

Mao Zedong. 1957. "Youth," https://www.marxists.org/reference/archieve/mao/works/red-book/ch30. htm. Accessed 27 June 2016.

Mao, Zedong. 1968. "A new storm against imperialism,” https://marxistleninist.wordpress.com/2008/ 12/26/two-articles-by-mao-zedong-on-the-african-american-national-question/. Accessed 10 May 2015.

Molloy, Ivan. 2001. Rolling Back Revolution: The Emergence of Low Intensity Conflict. London: Pluto Press.

Niccolai, Roberto. 1998. Quando la Cina era vicina: La Rivoluzione Culturale e la sinistra extraparlamentare Italiana negli anni '60 e '70. Pisa: Associazione centro de documentazione de Pistoia.

Priestland, David. 2010. The Red Flag: Communism and the Making of the Modern World. London: Penguin.

Reid, Donald. 2004. "Etablissement: working in the factory to make revolution in France." Radical History Review 88, 83-111. 
Ross, Andrew. 2005. "Mao Zedong's impact on cultural politics in the West." Cultural Politics 1(1), $5-22$.

Scott, David. 2007. China Stands Up: The PRC and the International System. Abingdon: Routledge. Seale, Bobby. 1991. Seize the Time: Story of the Black Panther Party and Huey P. Newton. Baltimore: Black Classic Press.

Seth, Sanjay. 2006. "From Maoism to postcolonialism? The Indian 'sixties,' and beyond." Inter-Asia Cultural Studies 7(4), 589-605.

Slobodian, Quinn. 2012. Foreign Front: Third World Politics in Sixties West Germany. Durham, NC: Duke University Press.

Smith, J., and André Moncourt. 2009. The Red Army Faction, A Documentary History: Volume 1, Projectiles for the People. Oakland, CA: PM.

Stanford, Maxwell. 1986. "Revolutionary Action Movement (RAM): A Case Study of an Urban Revolutionary Movement in Western Capitalist Society." MA diss., University of Atlanta.

Tompkins, Andrew S. 2013. "BETTER ACTIVE TODAY THAN RADIOACTIVE TOMORROW!' Transnational Opposition to Nuclear Energy in France and West Germany, 1968-1981." PhD diss., University of Oxford.

Wang, Hui. 2009. The End of the Revolution: China and the Limits of Modernity. London: Verso.

Wang, Ning. 2015. "Introduction: global Maoism and cultural revolutions in the global context." Comparative Literature Studies 52(1), 1-11.

Wolin, Richard. 2010. The Wind from the East: French Intellectuals, the Cultural Revolution, and the Legacy of the 1960s. Princeton, NJ: Princeton University Press.

Ye, Luofu. 2015. "Propaganda as leftist culture: Hong Kong's involvement in the Cultural Revolution." Comparative Literature Studies 52(1), 80-96.

Žižek, Slavoj. 2011. "Revolutionary terror from Robespierre to Mao." Positions 19(3), 671-706. 